\title{
Elihu jako mędrzec w historii egzegezy Księgi Hioba na przykładzie anonimowego Commentarii in Job
}

Elihu jest pierwszym spośród antycznych komentatorów w historii egzegezy Księgi Hioba. Jest on obecnie coraz bardziej popularny w badaniach nad Księgą Hioba. W kwestii wystąpienia Elihu większa część egzegetów przyjmuje pogląd, iż jego mowy są późniejszym dodatkiem z racji tego, że Elihu nie jest wspominany ani w prologu, ani w epilogu Księgi Hioba, język jego wystąpienia różni się od języka trzech przyjaciół Hioba, jego przemowy nie mają struktury dialogicznej, a nadto główny temat nauczania Elihu różni się od argumentów wysuwanych przez poprzedników w dyskusji ${ }^{2}$.

W niniejszym artykule postanowiliśmy zaprezentować postać mędrca Elihu na przykładzie anonimowego Commentarii in Job. Temat zosta-

Dr Magdalena Jóźwiak, współpracownik w Pracowni Starożytnego Bliskiego Wschodu i Tradycji Biblijnej w Instytucie Studiów Klasycznych, Śródziemnomorskich i Orientalnych Uniwersytetu Wrocławskiego. Lektor w Szkole Języków Antycznych i Orientalnych przy Wydziale Filologicznym Uniwersytetu Wrocławskiego, e-mail: mjozwiak.uni.wr@gmail.com, ORCID: 0000-0002-1253-1162.

2 Podstawowa literatura na temat mów Elihu przedstawia się następująco: G. Fohrer, Die Weisheit des Elihu, „Archiv für Orientalforschung” 19 (1959-1960) 8394; D.N. Freedman, The Elihu Speeches in the Book of Job. A Hypothetical Episode in the Literary History of the Work, HTR 61 (1968) 51-59; R. Gordis, Elihu the Intrude. A study of the Authenticity of Job, „Lown Institute Judaistic Studies” 1 (1963) 60-78; J. Vermeylen, Job, ses amis et son Dieu. La légende de Job et ses relectures postexiliques, Leiden 1986. Na temat ,tradycji Elihu” w późniejszej literaturze żydowskiej, zob. R.N. Carstensen, The Persistence of the 'Elihu' Tradition in Later Jewish Writers, „Lexington Theological Quarterly” 2 (1967) 37-46. W języku polskim warto odnotować następującą publikację: B. Strzałkowska, Mowy Elihu (Hi 32-37) oraz ich reinterpretacja w Biblii Greckiej, Warszawa 2009. W niniejszym przypisie cytujemy tylko podstawową bibliografię tematyczną. W celu zgłębienia tematyki, zob. wykaz bibliograficzny: A. Tronina, Księga Hioba. Wstęp, przekład z oryginału, komentarz, Częstochowa 2013, 653-670. 
nie przedstawiony w trzech odsłonach. Po pierwsze, omówimy pokrótce Commentarii in Job. Po drugie, nakreślimy obraz Elihu, jaki wyłania się z omawianego komentarza. W końcowym zaś i najważniejszym podpunkcie tego artykułu zreferujemy na podstawie Commentarii in Job stosunek mędrca Elihu do Boga, do Hioba i trzech jego przyjaciół. Fragmenty z Commentarii in Job podajemy w thumaczeniu własnym.

\section{Słów kilka o Commentarii in Job}

Zagadką, która do tej pory nie została całkowicie rozwiązana, jest Commentarii in $J_{o b}{ }^{3}$, czyli epitoma tekstu Filipa Prezbitera ${ }^{4}$, wydana po raz pierwszy przez Erazma z Rotterdamu w 1516 roku z kodeksu w Sankt-Gallen, który przypisuje to dzieło św. Hieronimowi. I tutaj sprawa zaczyna się komplikować, gdyż od wydania Erazma zaczęto błędnie utożsamiać Commentarii in Job, umieszczone przez Jacques'a Paula Migne'a w Patrologia Latina pod dziełami św. Hieronima, z In historiam Iob commentariorum libri tres autorstwa Filipa Prezbitera ${ }^{5}$. Włoska uczona Maria Pia Ciccarese, znalazłszy zaginione i zapomniane dzieło Filipa, przekonuje, że Commentarii in Job nie sposób identyfikować z rzeczywistym komentarzem do Księgi Hioba Filipa Prezbitera, gdyż epitoma w porównaniu z wydaniem Johannesa Sicharda ${ }^{6}$ wykazuje silne rozbieżności

3 Zob. PL 26, 619-802 oraz pierwsze tłumaczenie na język polski tego łacińskiego komentarza: Anonim, Komentarz do Księgi Hioba (Commentarii in Job), czyli epitoma «Komentarza do historii Hioba» Filipa Prezbitera, tł. M. Jóźwiak, Wrocław 2018. W oparciu o rozdziały 29-30 z owego komentarza do Księgi Hioba powstała również dysertacja doktorska, zob. M. Jóźwiak, „Job figuram Christi portavit”. Typologia HiobChrystus w anonimowym ,Commentarii in Job" na przykładzie komentarza do Hi 2930, Wrocław 2015, dys. PWT. Rozprawa doktorska została napisana pod kierunkiem ks. prof. M. Rosika w Instytucie Nauk Biblijnych na Papieskim Wydziale Teologicznym we Wrocławiu.

4 Na temat Filipa Prezbitera oraz jego interpretacji Księgi Hioba, zob. M. Jóźwiak, „, Komentarz do historii Hioba” Filipa Prezbitera, Wrocław 2015.

5 W swojej monografii na temat Filipa i jego dzieła wykazaliśmy na podstawie przesłanek odnalezionych w samym tekście, jak i opierając się na ogólnej wiedzy o Hieronimie, że Strydończyk nie jest autorem epitomy - jej autor pozostaje nam nieznany. Zob. Jóźwiak, ,, Komentarz do historii Hioba”, s. 50-57.

6 Zob. Philippi presbyteri viri longe eruditissimi in historiam Iob commentariorum libri tres, red. Johannes Sichardus, Basileae, per Adamum Petrum, mense Augusto, anno 1527 (=http://babel.hathitrust.org/cgi/pt?id=ucm.5316850776; view=1up;seq=1). 
i różni się znacznie od oryginału․ Sprawą tajemniczą jest, spod czyjego pióra wyszedł textus brevior i jaki cel przyświecał autorowi, że streścił komentarz Filipa Prezbitera ${ }^{8}$.

Pomimo odkrycia przez M.P. Ciccarese zaginionego komentarza do Księgi Hioba, napisanego przez Filipa, do dziś w monografiach naukowych traktujących o starożytnych komentarzach do tejże księgi panuje ogromne zamieszanie i nieład. Większość uczonych zupełnie nie posiada świadomości, iż Commentarii in Job znajdujące się w Patrologia Latina jest streszczeniem In historiam Iob commentariorum libri tres autorstwa Filipa Prezbitera, przez co uczeni ci Commentarii in Job błędnie przypisują Filipowi lub nazywają je po prostu „pseudohieronimowym”, ignorując zupełnie istnienie wersji obszerniejszej ${ }^{9}$.

Autor omawianego komentarza do Księgi Hioba stosuje dwojaki typ egzegezy: literalny oraz alegoryczny. Fenomenem epitomy jest fakt, że anonimowy komentator, tak jak Filip Prezbiter, odczytuje Hioba w kluczu chrystologicznym, który biegnie równoległe obok prezentacji Hioba jako postaci historycznej. Dla komentatora Hiob jest typem cierpiącego Chrystusa, którego zapowiada ${ }^{10}$.

\section{Prezentacja mędrca Elihu w komentarzu}

W Hi 32 pojawia się niezwykle tajemnicza postać - Elihu. Nosi to samo imię, co wielki prorok Eliasz, ,prorok jak ogień, a słowo jego płonęło, jak pochodnia" (Syr 48,1). Zgodnie z zasadami onomastyki żydowskiej imię zawiera w sobie pewien program. „On [Jahwe] jest moim Bogiem”ll

7 Por. M.P. Ciccarese, Una esegesi ,,double face”. Introduzione all' ,Expositio in Iob” del presbitero Filippo, ASE 9 (1992) 483-492.

8 W jednym $\mathrm{z}$ artykułów podjęliśmy próbę ukazania na wybranych passusach, w jaki sposób autor epitomy korzystał z komentarza Filipa Prezbitera. Spróbowaliśmy udzielić odpowiedzi na następujące pytania: czy anonimowy autor textus brevior dosłownie przepisuje interpretacje Filipa? Czy może dorzucił swój „kamień interpretacyjny” do wyjaśnienia Księgi Hioba? Zob. na ten temat: M. Jóźwiak, ,,Komentarz do historii Hioba” Filipa Prezbitera a epitoma tego dzieła. Przyczynek do badań porównawczych nad tymi tekstami, VoxP 34 (2014) 185-195.

9 Zob. Jóźwiak, ,, Komentarz do historii Hioba”, s. 42-45.

10 Zob. Jóźwiak, ,, Komentarz do historii Hioba”, s. 102-110.

11 Filip Prezbiter, choć w Komentarzu do historii Hioba często wyprowadza etymologię nazw własnych, jednak nie podaje znaczenia imienia Elihu, stąd anonimowy autor epitomy również nie zawarł takiej informacji. Mistrz Filipa św. Hieronim ze Strydonu 
- będzie to zatem nowy, rozogniony adwokat Boga, między innymi dlatego, że w tradycji rabinicznej Eliasz wyobrażał sędziego rozstrzygającego wszystkie spory Izraela i wydaje się, że nieprzypadkowo nosi on imię bardzo zbliżone do imienia wielkiego stróża tradycji.

Wyprowadzając genealogię Elihu, komentator odnotowuje, że był on synem Barakeela, zrodził się z pokolenia Buza i stąd jest nazywany Buzytą. Następnie przywołuje opinię, iż postać Elihu jest utożsamiana z wróżbitą Balaamem, który występuje w Księdze Liczb ${ }^{12}$, a którego król Balak sprowadził, aby przeklął Izraela. Na koniec podaje jeszcze klasyfikację według szczepu:

Z rodu i pokolenia Huza i Buza, synów Nachora i Milki, siostry Sary, żony Abrahama, rodzi się Hiob i Elihu. Z Huza rodzi się Hiob, a z Buza ten Elihu, dlatego i Buzytą jest nazywany, który był, jak tutaj odnotowano, synem Barakeela. Otóż najbardziej uczeni w Piśmie Świętym podają, że właśnie ten Elihu jest owym wróżbitą Balaamem, którego w Księdze Liczb sprowadził Balak, król Moabitów, aby przeklął Izraela i Pismo Święte podaje to, że ten Elihu był ze szczepu Ram i przyjmujemy, że Abraham jest z tego Ram, ze szczepu którego i rodziny Elihu został zrodzony ${ }^{13}$.

Autor komentarza wyjaśnia, że nie jest rzeczą dziwną, iż Elihu ma dwa imiona, gdyż jest to wielokrotnie praktykowane w Biblii. Król Salomon był nazywany Jedyniaszem, Jetro, krewny Mojżesza - Raguelem, a także pierwszy z apostołów, Piotr, to Szymon. Jednak komentator zaznacza, że owa różnorodność imion w Biblii wprowadza duże zamieszanie i często jest kłopotliwa dla czytelnika:

Kiedy zaś Elihu jest nazywany dwoma imionami, nie jest to dziwne, iż znane jest to $\mathrm{w}$ boskich Pismach, gdyż Salomon ${ }^{14}$ był nazywany Jedyniaszem ${ }^{15}$,

\footnotetext{
w Liber interpretationis hebraicorum nominum interpretuje imię Elihu jako Deus meus iste albo Deus Dominus (PL 23, 839), zgodnie z językiem hebrajskim od słów אֵ ('Bóg') i הוּא ('on'). Por. L. Koehler - W. Baumgartner - J.J. Stamm, Wielki stownik hebrajsko-polski i aramejsko-polski Starego Testamentu, t. 1, red. P. Dec, Warszawa 2008, 47-48, nr 463; 229-230, nr 2186.

12 Por. Lb 22,17.

13 Anonymus, Commentarii in Job 32, 2.

14 Zob. 1Krl 1,32-11,43; 2Krn 1,1-9,31.

15 W Filipowym Komentarzu do historii Hioba imię Jedyniasz (łac. Jedidia) występuje w zapisie Ididida, w epitomie zaś - Idida. Obydwie formy są najprawdopodobniej pomyłką w zapisie. Zgodnie z przekazem 2Sm 12,25 prorok Natan dał Salomonowi dru-

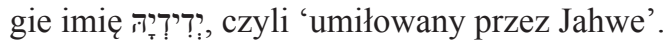


i Jetro ${ }^{16}$, krewny Mojżesza - Raguelem, a Piotr ${ }^{17}$, to Szymon. Stąd ta różnorodność imion zwykła dostarczać czytelnikom niemałą niejasność ${ }^{18}$.

Po podaniu korzeni rasowych i danych osobowych Elihu przedstawia się jeszcze jego ludzkie i osobiste cechy. Autor Commentarii in Job sugeruje, jakoby Elihu, choć był młodszy od swych przedmówców, uważa się za mądrzejszego i bardziej doświadczonego, ponieważ w swych mowach próbuje poprawiać wcześniejsze wypowiedzi, by stały się one bardziej uczone i sensowne albo też stara się obalić argumenty przedłożone przez Hioba ${ }^{19}$.

Komentator podaje, że Elihu wydawał się być człowiekiem sprawiedliwym i posiadał ducha proroctwa, lecz wypowiadał się bardzo chaotycznie i zbyt pospiesznie wydał niesprawiedliwy sąd o Hiobie:

Otóż ten Elihu, w istocie się pojawia zgodnie z porządkiem natury, wydaje się, że był człowiekiem sprawiedliwym i on posiadał ducha proroctwa, lecz sądzę, iż nie w tym samym stopniu czy też z tej samej łaski, jak święci prorocy. Dlatego i sam Pan powiedział do świętego Hioba o nim: „Kim jest ten okrywający myśli nierozumnymi słowami?” $(38,2)$. Jako że sens proroczy został podany za pomocą słów obelgi i w chaotycznych mowach, gdyż Pan nie gani [tego], że Elihu się wypowiada, lecz karci to, że zbyt pospiesznie wydaje sąd o nim $^{20}$.

Autor textus brevior pod koniec rozdziału trzydziestego drugiego akcentuje założenie młodego mędrca Elihu, którym będzie się kierował, przemawiając do Hioba. A mianowicie Elihu, przeprowadzając sąd nad Hiobem, powziął następujące postanowienie: „Takie jest postanowienie, rzekł, sprawiedliwego mego sądu, że ani nie oszczędzę człowieka wobec mówienia prawdy, ani nie zrobię krzywdy Bogu, abym twierdził, że on uczynił coś niesprawiedliwie"21.

A zatem Elihu, zapowiedziawszy bezstronność w sporze, zachęca Hioba, by wysłuchał wszystkich jego argumentów. Wydaje się, że takie

16 Zob. Wj 2,16-21; 3,1; 18,12; 18,17-24.

17 Zob. Mt 16,17-18.

18 Anonymus, Commentarii in Job 32, 2.

19 Anonymus, Commentarii in Job 32, 6-9: „Należy wiedzieć, że ten Elihu przez cztery mowy, tak jak poucza tekst lekcji, wypowiada się po sobie samym; próbuje przez te poszczególne mowy albo poprawiać odpowiedzi wcześniejszych, jakby bardziej uczenie, albo pojedyncze miejsca wypowiedziane kąśliwiej przez świętego Hioba, [próbuje] obalić w jego obecności".

20 Anonymus, Commentarii in Job 32, 2.

21 Anonymus, Commentarii in Job 32, 21-22. 
traktowanie cierpiącego człowieka dowodzi szorstkiego charakteru młodego mędrca, który, można by przypuszczać, uważa swoje słowa za natchnione, gdyż podobnie jak Adam został ukształtowany przez „ducha” Bożego i ożywiło go „tchnienie” Boże (por. Hi 32,8).

W przekonaniu autora epitomy Elihu jest symbolem pogan, o czym zaświadcza już na początku komentarza do rozdziału trzydziestego drugiego, a trzej przyjaciele Hioba (Bildad, Elifaz i Sofar) są figurą heretyków ${ }^{22}$ : „I tak powiedzieliśmy, że ten Elihu, który jest Balaamem, zawiera w sobie figurę pogan przeciwnych Chrystusowi, tak jak i owi przyjaciele błogosławionego Hioba [są] figurą heretyków"23.

Taka charakterystyka stanowi zupełne novum w linii interpretacyjnej Księgi Hioba, ponieważ Filip Prezbiter, a za nim jego naśladowca - autor Commentarii in Job, jako pierwsi spośród starożytnych komentatorów sugerują, że trzej przyjaciele Hioba są figurą heretyków, a tajemniczy rozmówca Elihu jest obrazem pogan. Zatem Filip i anonimowy kontynuator jego dzieła dorzucili do ,przewodnika” po biblijnej Księdze Hioba swój „kamień interpretacyjny”.

22 W omawianym komentarzu występują bardzo ciekawe alegorie heretyków, którzy są nazywani między innymi „nieprzyjaciółmi Kościoła” (zob. 2, 12-13), „rozdzierającymi wiarę” (zob. 2, 12-13), „popadającymi w bluźnierstwo” (zob. 2, 12-13), „przesuwającymi granice, czyli rabusiami” (zob. 24, 2), „mordercami” (zob. 24, 14), „złodziejami” (zob. 24,14 ) oraz „fałszerzami” (zob. 24, 15). Dla przykładu heretycy zostali porównani z mordercami, gdyż jak morderca uśmierca ciało człowieka, tak oni uśmiercają duszę ludzką, prezentując innym swe zgubne poglądy. Wszyscy heretycy wyłonili się z Kościoła na skutek sporów podyktowanych fałszywym rozumieniem doktryny i głoszą oni zniekształconą naukę. Do grona tych od czasu zmartwychwstania Chrystusa dołączyło mnóstwo nowych morderców, którzy szerzą herezje: „Albo inaczej: tutaj zatem morderca słusznie jest rozumiany jako każdy heretyk z grona tych, którzy zabijają dusze ludzi krzywdami i poglądami śmierć przynoszącymi. Kiedy zaś mówi: «wczesnym rankiem wstaje», czyli, ponieważ gdy ci, którzy dopiero co zostali wtajemniczeni w wiarę, mają poranek, to znaczy, jakby początek w świętej religii albo ci powstali o poranku, gdy z ciemności i synów nocy stali się w Panu synami Boga; tamci zaś spieszą podać jad swego wiarołomstwa, aby ich omamić. Albo inaczej: «Rankiem» należy odnieść do Chrystusa, ponieważ po jego zmartwychwstaniu, herezje zaczęły być obecne w Kościele" (Anonymus, Commentarii in Job 24, 14).

23 Anonymus, Commentarii in Job, 32, 2. 


\section{Stosunek mędrca Elihu do poszczególnych bohaterów histo- rii Hioba na podstawie anonimowego Commentarii in Job}

Elihu po captatio benevolentiae wyrażonej w słowach: „Co do lat jestem młody, wy zaś jesteście już starzy: stąd się przeląkłem, strwożyłem, nie ujawniłem swej wiedzy. Niech mówią lata - myślałem, podeszły wiek jest rozumny" (Hi 32,6-7) odważnie wprowadza rewolucyjną wizję mądrości. Jest ona nie tyle owocem ludzkich zdobyczy, ile raczej boskim charyzmatem. A zatem po kapitulacji trzech przyjaciół Hioba głos w sprawie Hiobowej zabiera młody Elihu.

\subsection{Mędrzec Elihu versus Bóg}

W omawianym komentarzu Elihu jest przede wszystkim obrońcą Boga. W jego przekonaniu Bóg jest sprawiedliwy i nie karci nikogo niesłusznie, o czym poucza Hioba w słowach:

Gdyby ktoś podobnym zdołał być do niego, podobnym w mocy i cnocie, i zdołałby ukazać się jako podobny w sprawiedliwości i w mądrości, i w mnogości prawa, a także w sądach jego. I dlatego zrozum, mówi, że nikt niesłusznie nie może być karcony przez Boga, który sam jeden jest i mężny, i mądry ${ }^{24}$.

Komentując Hi 37,23-24, Elihu zaświadcza, że Bóg jest niepojęty, a sądy Jego są słuszne i prawe. Bóg w głębokiej rzeczywistości swego bytu jest ponad wszelkim zrozumieniem. Jeśli Bóg jest niedostępny, jeśli jego atrybutami są nieskończona moc, prawość i sprawiedliwość, to nie może on niesprawiedliwie uciskać człowieka:

Mówi: ponieważ jak Bóg jest wielki i potężny w mocy, tak jest rzetelny w sądzeniu i sprawiedliwości i nie może być opisany. Dlatego podobnie jak stworzenie jego nie może go odnaleźć, które tak bardzo jest słabe $\mathrm{i}$ bezsilne, to $\mathrm{z}$ tego powodu wielcy i rozumni mężowie nie będą śmiali badać niepojętego ani nie będą próbować kontemplować niewidzialnego. A mianowicie to wszystko zostało powiedziane, aby wyszydzić świętego Hioba, który powiedział, że jest chłostany przez Boga bez żadnej winy grzechu ${ }^{25}$.

\footnotetext{
24 Anonymus, Commentarii in Job 36, 22.

25 Anonymus, Commentarii in Job 37, 23-24.
} 
Analizując passus z Hi 33,12-18, autor epitomy wyjaśnia, iż mędrzec Elihu poucza o metodach karcenia i upominania stosowanych przez Boga względem grzeszników. A mianowicie Bóg upomina człowieka w nocnych widzeniach i poprzez choroby:

Bóg jeden raz przemawia i po raz drugi nie powtarza tego samego" (Hi $33,14)$, to znaczy Bóg się nie odmienia, tylko zmiana naszego życia będzie wymagała właśnie tego; w tym miejscu Elihu dokładnie opowiada o dwóch pewnych drogach upomnień i mówi, że boska nauka czy też karcenie skierowane do człowieka ma miejsce i w nocnych widzeniach i także na łożu $[\ldots]^{26}$.

Następnie komentator powołuje się na przykłady zaczerpnięte z Pisma Świętego, by uargumentować swoje wcześniejsze spekulacje. Wylicza, iż pośród tych, którzy zostali upomniani w snach, znajdują się Nabuchodonozor ${ }^{27}$, Laban $^{28}$, Abimelek ${ }^{29}$, żona Piłata ${ }^{30}$, magowie w Ewangelii ${ }^{31}$ oraz patriarcha Jakub ${ }^{32}$. Do tych natomiast, których Bóg upomniał przez chorobę, zalicza paralityka, któremu Pan odpuścił grzechy $^{33}$. Autor Commentarii in Job zaznacza, że są i tacy, jak na przykład Trofim $^{34}$ i Epafrodyt ${ }^{35}$, którzy uchodzili za sprawiedliwych, a jednak byli doświadczani przez choroby. Ich cierpienie traktuje jako próbę, której zostali poddani:

Natomiast przykład obecnych sytuacji, o których teraz mówimy, odnajdujemy w Pańskich Pismach, kiedy czytamy, że ludzie byli w snach upominani, jak na przykład Nabuchodonozor - król najbardziej pyszny i Laban, który planował zgubę Jakuba, krewniaka swego, i król Abimelek, który próbował zhańbić dom świętego Abrahama, i żona Piłata, która rzekła do niego o Panu naszym - Jezusie Chrystusie: „Nic tobie i temu sprawiedliwemu, bowiem wiele z jego powodu wycierpiałam we śnie". I magowie w Ewangelii zostali ostrzeżeni w widzeniach sennych, aby wyruszyli inną drogą. Także wierni mężowie są w snach pouczani przez Boga, tak jak patriarcha Jakub, i czyta-

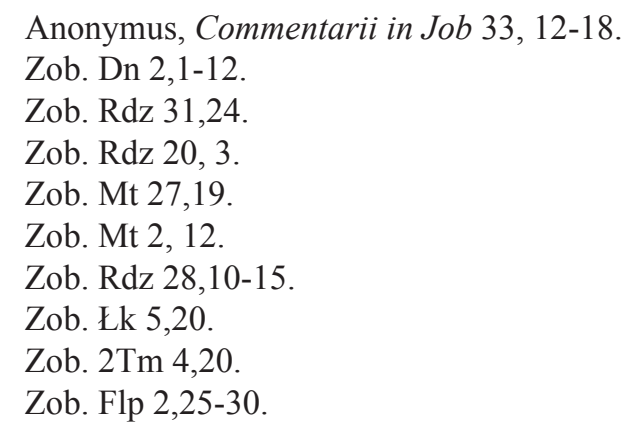


my, iż inni byli osłabieni z powodu grzechów, wiemy, że wśród nich był ów paralityk, do którego Pan rzekł: „Zostają odpuszczone tobie twe grzechy”. I czytamy, że święci byli chorzy, na przykład Trofim i Epafrodyt, z pewnością powinniśmy przyjąć, że ci, choć sprawiedliwi, zostali wypróbowani przez takie upomnienie, gdyż nie jako grzesznicy byli smagani razami choroby ${ }^{36}$.

Adwokat Boga w komentarzu do Hi 35,14 rozsądza sprawę w kwestii zasady odpłaty. Doradza Hiobowi, aby czekał, a dowód będzie oczywisty. Mędrzec Elihu wyjaśnia, że Bóg nie od razu oddaje grzesznikom to, na co zasługują. Zapłata przyjdzie w swoim czasie:

Kiedy widzisz, Hiobie, że Bóg nie od razu oddaje grzesznikom, na co zasługują, nie chciej być złamanym wskutek małoduszności, tak że popadasz w bluźnierstwo i mówisz, że Bóg [jest] niesprawiedliwy lub wrogi, lecz powinieneś sądzić z nim, to znaczy zgadzać się z jego sądami, a nie na przekór jemu przez zarozumiały swój sąd posuwać się do obrazy go ${ }^{37}$.

A zatem Elihu na każdym kroku okazuje się obrońcą Boga. Jego mądrość pochodzi z wysoka i jest mądrością apologetyczną, ponieważ przyznaje rację Bogu, broniąc go przed oskarżeniami Hioba. Jest to mądrość doskonała, niemal jak ta boska, co może sugerować termin צִָ̣ ('wiedza'), który w liczbie mnogiej odnosi się wyłącznie do Boga ${ }^{38}$. Elihu, stając po stronie Boga, żywi nadzieję, że sprawa Hiobowa zostanie definitywnie rozwiązana i zamknięta.

\subsection{Mędrzec Elihu versus Hiob}

Po kapitulacji trzech przyjaciół Hioba wyrażonej w słowach: „Znaleźliśmy mądrość, Bóg go pokona, nie człowiek” (Hi 32,13) Elihu wysuwa swoją kandydaturę, by wydać sąd w sprawie Hioba. Słowa, które wyjdą z ust Elihu, nie będą słowami pochlebstwa ani w stosunku do Hioba, ani wobec jego przyjaciół. Będą to słowa odpowiedzi. Na koniec Elihu dołącza do swych słów złorzeczącą przysięgę: „wnet by mnie Stwórca usunął" (Hi 32,22). Tym samym zaklina się, że jeśli jego słowa nie będą autentyczne, to zostanie usunięty z powierzchni ziemi. A zatem, w jego przekonaniu, sam Stwórca będzie gwarantem natchnienia młodego mędr-

36 Anonymus, Commentarii in Job 33, 19-24.

37 Anonymus, Commentarii in Job 35, 14.

38 Por. Koehler - Baumgartner - Stamm, Wielki słownik hebrajsko-polski, t. 1, 217 218, nr 2090. 
ca. Elihu w swych mowach przyjmuje metodę polegającą na swobodnym streszczaniu pewnych wcześniejszych stwierdzeń Hioba, z którymi chce podjąć dyskusję krytyczną. Już na początku rozdziału trzydziestego trzeciego poddaje ocenie twierdzenie Hioba: „Ja jestem czysty i niesplamiony, bez grzechu i nie ma we mnie nieprawości" (Hi 33,9). Młody mędrzec zasadniczo kontestuje przekonanie Hioba o swej niewinności, co akcentuje autor Commentarii in Job, powątpiewając oczywiście w ten osąd:

Otóż Elihu to mówi Hiobowi: Przeto nie jesteś w tym sprawiedliwy, to znaczy powinieneś ganić siebie, a nie chwalić, nie [powinieneś] mówić tego: „Czysty jestem, bez grzechu i niesplamiony, także nie ma we mnie nieprawości" (Hi 33,9). To znaczy powtarzam, nie jesteś w tym sprawiedliwy, ponieważ prawość zdobywa się poprzez pokorę. Natomiast sława pychy sprowadza potępienie. Z pewnością, jako sprawiedliwy mąż mógł mówić Bogu o swoich świętych dziełach, słusznie o tym przekonany, [mógł] śmiało [wspominać] o tych, które są prawdziwe, jednak nie mógł mówić o tych, które Elihu jemu fałszywie zarzuca, jakoby [był] bezbożnikiem ${ }^{39}$.

Stopniowo atak Elihu na Hioba staje się coraz bardziej agresywny. Młody mędrzec kreśli szkic Hioba jako człowieka obłudnego, podstępnego i niegodziwego, porównując go do grzeszników, Żydów oraz heretyków. Analizując Hi 36,13 („,Obłudnicy i podstępni wywołują gniew Boga i nie zakrzyczą, gdy zostaną związani”), anonimowy komentator odnotowuje:

Widać bardzo wyraźnie, że Elihu w tym [miejscu] godzi w samego świętego Hioba, jak gdyby za pomocą aluzji, że i on właśnie, jakoby postępował podstępnie i niegodziwie, a także udawał męża wybranego przez Boga. I że ten, gdy był skrępowany więzami tego nieszczęścia, zupełnie nie dbał o to, by wołać do Boga i przyzywać go, aby związany został uwolniony od bolesnych kajdan, mianowicie ponieważ kierował się rozpaczą lub pogardą. Podobnie to samo można odnieść do pozostałych grzeszników, którzy, gdy zejdą na dno złych [czynów], lekceważą to, a [także można odnieść to] do Żydów i heretyków, którzy okrywają się fałszywymi dogmatami jakby szatą prawdy i trwają $\mathrm{w}$ przewrotności nocy $\mathrm{z}$ racji upartego i szczelnie zamkniętego serca ${ }^{40}$.

Dalej Elihu oskarża Hioba o gniew i żądzę zysku, napominając go, aby nie trwał dłużej w gniewie, kiedy jest pogrążony w ciemnościach próby. Cierpienie jest ceną jego okupu: im jest ono okrutniejsze, tym wspanialsze

\footnotetext{
39 Anonymus, Commentarii in Job 33, 8-9.

40 Anonymus, Commentarii in Job 36, 13.
} 
będzie wyzwolenie. W tym sensie cierpienie staje się narzędziem przebłagania.

Młody mędrzec wyrzuca także Hiobowi, że jest grzesznikiem. Werset 36,20 jest tak samo mroczny jak ,noc”, którą Elihu wprowadza na scenę: „Nie przedłużaj nocy, aby ludy powstały wobec tych [występków]”. W tym passusie Elihu zaprasza Hioba, by nie życzył sobie nocy śmierci, bo jego cierpienie ma ukryty sens, a zostało mu ono nałożone na jego barki po to, by go oczyścić. Mędrzec napomina Hioba, by odstąpił od swych grzechów, wówczas zazna spokoju. Autor Commentarii in Job, komentując ów werset, wkłada w usta Elihu słowa następującej treści:

Już wystarczy, że tak długo żyłeś w tej ślepocie. Teraz staraj się dotrzeć do światła roztropności i prawości albo mówi: błagam, nie przedłużaj już dalej nocy, którą utkałeś dla siebie z różnych grzechów, abyś kroczył w niej jakby w ciągłych, a także ustawicznych i nieustających ciemnościach i dodając grzech do grzechu cieszysz się, że przeciągasz [ją] daleko jakby sznur; otóż wobec światła tej nagany połóż już kres tym grzechom, albowiem przez to przedłużanie twoje życie stanie się nie do uleczenia, gdyż wobec wszystkich twoich złych czynów prośby ludów znajdą się przed Bogiem, naturalnie [tych], których bardzo niesłusznie uciskasz, skarżących się na ciebie i kładących przed tronem boskiej sprawiedliwości swe cierpienia zadane im przez ciebie $^{41}$.

Elihu nie pozostaje neutralny, kiedy chodzi o apologię Boga. Hiob powinien być poddany przesłuchaniu, gdyż mówi nierozważnie i dopuścił się bluźnierstwa przeciwko Bogu. W anonimowym komentarzu do Hi 34, 37 czytamy: „Ten dodał do grzechów swoich bluźnierstwo”. To znaczy oprócz tego, że jest grzesznikiem, dodaje do zbioru grzechów to, iż wpadł w występek bluźnierstwa, z tego powodu cierpi te [wszystkie] nieszczęścia ${ }^{42}$.

Według logiki młodego mędrca Hiobowi pozostało jedno rozwiązanie. Skoro jest metafizycznie niemożliwe, aby Bóg był niesprawiedliwy lub się mylił, to Hiob ma przed sobą tylko jedną drogę, a mianowicie nawrócenie. Autor epitomy przypisuje Elihu takie oto słowa:

Wielką jest rzeczą i niesamowicie miłą dla Boga, jak człowiek nie wstydzi się przyznać do swoich błędów, zwłaszcza jeśli rozumie, że on przez nie jest karcony i tak pokornieje, że zniesie całość karcenia i wyzna, że cierpienie [jest] zbyt małe w stosunku do jego przewin ${ }^{43}$.

\footnotetext{
41 Anonymus, Commentarii in Job 36, 20.

42 Anonymus, Commentarii in Job 34, 37.

43 Anonymus, Commentarii in Job 33, 27.
} 
A zatem Elihu twierdzi, że Hiob nie może niczego dobrego spodziewać się od Boga, jeśli nie porzuci swych grzechów. Mędrzec zaleca Hiobowi, aby przestał przywoływać swoją niewinność jako argument przeciw Bogu. Niech Hiob przyjmie do wiadomości, że Stwórca kieruje światem zgodnie ze swą pedagogiką. Skarcony przez Boga Hiob powinien się nawrócić i przyłączyć do chóru mędrców opiewających mądrość Bożą. Zatem młody mędrzec okazuje się na każdym kroku apologetą Boga.

\subsection{Mędrzec Elihu versus trzej przyjaciele Hioba}

W Hi 33,4 czytamy: „Mnie [także] stworzył Duch Boży i tchnienie Wszechmocnego mnie ożywiło". Poprzez te słowa Elihu komunikuje, iż został obdarowany tym samym natchnieniem, które posiadał prorok, w miejscu którego siebie stawia. Młody mędrzec jest przekonany, że w tej trudnej sytuacji może przytoczyć lepsze argumenty niż te przywołane przez trzech przyjaciół Hioba. Jako naczynie Ducha Bożego, który napełnił go mądrością, czuje się zobligowany zabrać głos. Pośrednio zdaje się on wypowiadać do poprzednich rozmówców słowa psalmisty: „Jestem roztropniejszy od wszystkich, którzy mnie uczą, [...] jestem roztropniejszy od starców" (Ps 119,99-100), bo otrzymał dar Ducha Bożego i jego mądrości44.

W przekonaniu autora Commentarii in Job głównym powodem wystąpienia Elihu był fakt, iż przyjaciele Hioba nie zdołali udzielić racjonalnej i wyczerpującej odpowiedzi na pytanie, dlaczego Hiob cierpi. Tym samym Elihu wyraża gotowość podjęcia tego tematu w oparciu o otrzymane natchnienie: „Zatem i ja, mówi Elihu, spróbuję udzielić odpowiedzi za pomocą mych sił i ukażę wam, a także Hiobowi moją wiedzę, co dobitnie wskazuje na to, iż on [tak] mówi wskutek przechwalania się zarozumiałością [...]" ${ }^{\prime 4}$.

44 Anonymus, Commentarii in Job 33, 4: „Skoro tak powiedział, to podaje siebie za autorytet godny słuchania, ponieważ ten, który został uczyniony przez Ducha Boga i został ożywiony tchnieniem Wszechmocnego, nie może mówić [niczego] niesłusznego i nieprawdziwego, gdzie powinniśmy dostrzec Boga Trójcy. Bowiem w Bogu wymienia Ojca, we Wszechmocnym - Syna, w Duchu - Ducha Świętego. Mianowicie Bóg Trójcy stworzył wszystko, lecz kiedy uczynił człowieka, zechciał przez różnorodne nazywanie działań objawić, że on [otrzymał] właściwą sobie i jakąś indywidualną cechę osób, tak jak mówi nadający Prawo: «I stworzył Bóg człowieka, na obraz Boga go stworzył, uczynił ich mężczyzną i kobietą» (Rdz 1,27). I także: «I uczynił Bóg człowieka z prochu ziemi. I tchnął w jego osobę tchnienie życia i stał się człowiek na wzór duszy żyjącej» (Rdz 2,7), gdzie w stwarzaniu i tchnieniu ducha czy też w błogosławieniu, powinniśmy dostrzec bez żadnego wyłączenia czy też różnicy woli, że działa Trójca".

45 Anonymus, Commentarii in Job 32, 16-17. 
Przyjaciele Hioba kierują się klasyczną zasadą odpłaty, wedle której grzech pociąga za sobą cierpienie, zatem kto cierpi, musi być winny ${ }^{46}$. Nie przyjmują do wiadomości żadnych zastrzeżeń i chcą swoje rozumowanie narzucić Hiobowi. Dla przykładu, wyjaśniając passus: „I wzmacniałeś omdlałe ręce. Twe słowa podnosiły chwiejących się na duchu i wzmacniałeś drżące kolana. Teraz zaś nieszczęście przyszło na ciebie i zostałeś osłabiony, dotknęło ciebie i zaniepokoiłeś się. Gdzie jest twoja bojaźń, twoje męstwo, twoja cierpliwość i doskonałość twych dróg?" (Hi 4,3-6), komentator sugeruje, że Elifaz, posługując się szyderstwem, poucza Hioba, że gdyby postępował on sprawiedliwie, to nigdy nie spadłyby na niego tak wielkie nieszczęścia, które dobry i sprawiedliwy Bóg zesłał ku przestrodze dla innych:

Przeto te [słowa] zostały wypowiedziane z szyderstwem wobec świętego Hioba i mają taki sens: gdybyś czynił to, o czym mówiłem, nigdy nie popadłbyś w te nieszczęścia jako przykład dla śmiertelników, ponieważ wiemy, że Bóg jest dobrym i sprawiedliwym Stwórcą wszystkich rzeczy ${ }^{47}$.

Anonimowy egzegeta, komentując werset: „Czy Bóg obala sąd albo Wszechmocny niszczy, co sprawiedliwe jest?" (Hi 8,3), oświadcza, że Bildad, powołując się na Bożą sprawiedliwość, mówi, że Hiob cierpi to, na co sobie zasłużył: „Mówi, że według sprawiedliwości Boga cierpisz to, na co sobie zasłużyłeś" 48 .

W innym miejscu komentator podkreśla, że trzeci przyjaciel Hioba Sofar jest wzburzony zachowaniem Hioba, który trzyma się twierdzenia, że jest niewinny i uparcie oświadcza, iż znosi cierpienia bez słusznej przy-

46 Klasycznym tekstem stawiającym zasadę zwaną często „prawem dwóch dróg”, które wiąże się z ideą odpłaty, jest passus z Pwt 30,15-18. Teoria ta ma różne wymiary i formy w samej Biblii, gdyż istnieje odpłata dla konkretnej osoby za jej czyny (zob. Prz 11,21.31; Prz 19,17; Hi 1,9; 22,2), jak i jest odpłata zbiorowa (zob. Wj 20,5; 34,7; Sdz 3,7-8; 2Sm 24,15-16; Syr 11,20-28; Koh 9,5). Raz jest odpłata bezpośrednia i tymczasowa, innym razem odłożona do śmierci (zob. Ps 37,10; Ps 49,17-18; Ps 73,18-19; Hi 8,8; Syr 11,26-28). Z kolei autor Księgi Mądrości poucza o odpłacie eschatologicznej. Według jego sądu po śmierci dusze sprawiedliwych są oddzielane od dusz złoczyńców (zob. Mdr 3,1-5.10). W innym z artykułów postanowiliśmy poszukać odpowiedzi na pytania, w jaki sposób Filip Prezbiter, mistrz anonimowego autora Commentarii in Job, mierzy się z problematyką niezawinionego cierpienia i w jakim kierunku idą jego refleksje. Czy Hiob cierpi, gdyż dopuścił się grzechu? Czy może jest niewinny? A jeśli jest niewinny, to jaka jest przyczyna Hiobowego cierpienia? Zob. M. Jóźwiak, Idea niezawinionego cierpienia w „, Komentarzu do historii Hioba” Filipa Prezbitera, CT 85 (2015) nr 2, 83-93.

47 Anonymus, Commentarii in Job 4, 3-6.

48 Anonymus, Commentarii in Job 8, 3. 
czyny: „Dlatego, rzekł, jestem wzburzony i zmieszany w myśli, ponieważ mówisz, że ty znosisz te cierpienia [zesłane] przez Boga bez słusznej przyczyny, kiedy nie powinno się podejrzewać Boga o żadne zło"49.

Hiob, odpowiadając przyjaciołom, twierdzi, że jest niewinny i przekonuje, że nie uczynił nic wbrew przykazaniom Boga, co anonimowy autor epitomy niejednokrotnie podkreśla. Hiob wyjaśnia, że bał się nawet dopuścić do siebie najmniejszych grzechów, aby za te nie nadeszła na niego kara Boża: ,Zatem bałem się dopuścić [do siebie] najmniejszych grzechów, aby za te nie nadeszła na mnie kara Boga i oto teraz tak bardzo jestem karany, jakbym dopuścił się straszliwych występków"50. Trzej przyjaciele zaś są głusi na Hiobową argumentację i trzymają się swych idei, usiłując przekonać go o winie. Zachęcają Hioba do wyznania grzechów i zawierzenia się miłosierdziu Boga.

W tej Hiobowej bezradności do akcji wkracza Elihu. Wobec trzech przyjaciół Hioba zajął on własne stanowisko. W przekonaniu młodego mędrca cierpienie jest pedagogiczną karą, która ma na celu zmuszenie człowieka do uznania swej grzeszności, by ochronić go przed pychą. Cierpienie ma zatem wymiar oczyszczający, a wszystkie postanowienia Boga względem ludzi są racjonalne i sprawiedliwe ${ }^{51}$.

\section{Podsumowanie}

Elihu, zgromiwszy na początku swych mów Hioba za to, iż czynił się bardziej sprawiedliwym od Boga, oraz zapłonąwszy gniewem na trzech przyjaciół Hioba, bo nie potrafili udzielić mu odpowiedzi, w ostateczności przypisał mądrość sobie. W przekonaniu młodego mędrca mądrość nie jest uzależniona od wieku i doświadczenia, lecz duch Boży mieszka w ludziach i udziela im objawienia jako źródła wiedzy. Duch Boży obecny w duszy mędrca uzdalnia go do roztropnej mowy. Młody Elihu postuluje zatem charyzmatyczność mądrości. To nowe podejście nie jest tylko usprawiedliwieniem słuszności jego wystąpienia, ale jest także źródłem nowej epistemologii, która w Piśmie Świętym ma doskonałe świadectwo w refleksji antropologicznej zawartej w Księdze Mądrości.

49 Anonymus, Commentarii in Job 20, 1-2.

50 Anonymus, Commentarii in Job 6, 16.

51 Anonymus, Commentarii in Job 32, 6-9: „Czwarta zaś mowa Elihu zawiera to, co ma zamiar powiedzieć w obronie Boga, a dowodzi, że Bóg jest sprawiedliwy w swym postępowaniu, co pośród tajemnic swego proroctwa, aż do końca tej swojej czwartej mowy najzacieklej i z największą gorliwością przedkłada i nie ustępuje". 


\title{
Elihu jako mędrzec w historii egzegezy Księgi Hioba na przykładzie ano- nimowego Commentarii in Job
}

\author{
(streszczenie)
}

Elihu jest pierwszym spośród antycznych komentatorów w historii egzegezy Księgi Hioba. W kwestii wystąpienia Elihu większa część egzegetów przyjmuje pogląd, iż jego mowy są późniejszym dodatkiem, wysuwając przy tym szereg argumentów (m.in. Elihu nie pojawia się w prologu ani w epilogu Księgi Hioba, język jego wystąpienia różni się od języka trzech przyjaciół Hioba, główny temat nauczania Elihu różni się od argumentów wysuwanych przez poprzedników w dyskusji). W niniejszym artykule omówiliśmy postać mędrca Elihu na przykładzie anonimowego Commentarii in Job. Temat został przedstawiony w trzech odsłonach. Po pierwsze, zaprezentowaliśmy pokrótce Commentarii in Job. Po drugie, nakreśliliśmy obraz Elihu, jaki wyłania się z anonimowego komentarza. W końcowym zaś i najważniejszym podpunkcie tego artykułu zreferowaliśmy na podstawie Commentarii in Job stosunek mędrca Elihu do Boga, do Hioba i trzech jego przyjaciół. Fragmenty z omawianego komentarza podajemy w tłumaczeniu własnym.

Słowa kluczowe: Elihu; starożytne komentarze do Księgi Hioba; Anonim; Commentarii in Job

\section{Elihu as a Sage in the History of Exegesis of the Book of Job on the Example of Anonymous Commentarii in Job}

(summary)

Elihu is the first amongst the ancient commentators in the history of exegesis of the Book of Job. Currently, he is becoming more and more popular as a subject of research on the Book of Job. Regarding the Elihu's appearance, most of exegetes take the view that his speech must have been included in the Book of Job at a later time, because Elihu had been mentioned neither in the prologue, nor in the epilogue of the original text. Also, the language of his articulation differs from the language of Job's three other friends. Additionally, his speeches don't show the structure of a dialogue, and the main subject of Elihu's speech differs from arguments put forward by his predecessors in discussion. In this present article I analysed the person of Elihu on the example of anonymous Commentarii in Job. This subject has been presented in three scenes. Firstly, I summarised Commentarii in Job that was also a subject of my Ph.D. dissertation. Secondly, I drew the image of Elihu, as it emerges from the analysed commentary. The final and the most important section depicts Elihu's relation to God, to Job and Job's three friends, based on Commentarii in Job. Fragments of Commentarii in Job are the author's own translations.

Keywords: Elihu; ancient commentaries on the Book of Job; Anonymus; Commentarii in Job 


\section{Bibliografia}

\section{Źródła}

Anonymus, Commentarii in Job 32-37, PL 26, 721 C-745 B; tł. M. Jóźwiak, Anonim, Komentarz do Księgi Hioba (Commentarii in Job), czyli epitoma „Komentarza do historii Hioba" Filipa Prezbitera, Wrocław 2018, 278-331.

Hieronymus, Liber interpretationis hebraicorum nominum, PL 23, 839.

\section{Opracowania}

Ciccarese M.-P., „Una esegesi „,double face”. Introduzione all' „Expositio in Iob” del presbitero Filippo", ASE 9 (1992) 483-492.

Jóźwiak M., ,Komentarz do historii Hioba” Filipa Prezbitera a epitoma tego dzieła. Przyczynek do badań porównawczych nad tymi tekstami, VoxP 34 (2014) 185-195.

Jóźwiak M., ,,Komentarz do historii Hioba” Filipa Prezbitera, Wrocław 2015.

Jóźwiak M., Idea niezawinionego cierpienia w „Komentarzu do historii Hioba” Filipa Prezbitera, CT 85 (2015), nr 2, 83-93.

Koehler L. - Baumgartner W. - Stamm J.J., Wielki stownik hebrajsko-polski i aramejsko-polski Starego Testamentu, t. 1-2, red. P. Dec, Warszawa 2008. 